\title{
Low-Carbon Agriculture in Poland: Theoretical and Practical Challenges
}

\author{
Arkadiusz Piwowar* \\ Faculty of Engineering and Economics, Wroclaw University of Economics, Wroclaw, Poland
}

Received: 13 March 2018

Accepted: 12 June 2018

\begin{abstract}
Agriculture in Poland is one of the major sources of emissions of gaseous pollutants. In this respect, Polish agriculture is facing many difficult challenges, including reduction of ammonia and greenhouse gas emissions from livestock production and emissions of nitrous oxides and suboxides from manure and mineral fertilizers. Reducing emissions of, among others, gas from agriculture requires the introduction of innovative techniques and tools to increase the efficiency of agricultural production and waste from livestock and crop residues. The main objective of this paper is to outline the problem of low carbon agriculture in Poland, with particular emphasis on emissions of methane and nitrous oxide. This paper presents the main determinants and problems related to the development of low-carbon agriculture in Poland. The source of information for writing the paper was literature of the subject and statistical data of the Central Statistical Office.
\end{abstract}

Keywords: agricultural emissions; greenhouse gases; low carbon agriculture; Poland; sustainable development

\section{Introduction}

The term "low-carbon economy" has no universally accepted definition [1-3]. For the purposes of this paper it was assumed that "low-carbon economy is a whole series of actions that contribute to reducing greenhouse gas emissions while respecting the principles of sustainable development, oriented for innovation and competitiveness on the global market" [4]. The lowcarbon (low-emission) economy is the core model within the European Union's climate policy [5-7]. The term "low-carbon agriculture" is used here to cover actions to reduce the energy inputs to and GHG emissions from

*e-mail: arkadiusz.piwowar@ue.wroc.pl agriculture, with progress being a good indicator of improving environmental sustainability. Furthermore, carbon (C) is used as short-hand for all greenhouse gases. Putting the focus in analyses in the scope of the low-carbon economy in rural areas almost exclusively on $\mathrm{CO}_{2}$ emissions, without taking into account other gases, is unjustified and results in an underestimation of the volume of emissions and hinders the selection of appropriate directions of low-carbon development in these areas [8]. The issue of limiting greenhouse gas (GHG) emissions from anthropogenic sources is one of the main topics discussed by the scientific community and the political class [9-11]. The agricultural sector is one of the largest anthropogenic sources of GHG emissions [12, 13]. Carbon dioxide, methane and nitrous oxide emissions from agricultural sources play a significant role in the overall enhancement of the global 
greenhouse gas effect [14-16]. The main agricultural sources of greenhouse gas emissions are: $\mathrm{N}_{2} \mathrm{O}$ from soil, $\mathrm{CH}_{4}$ from enteric fermentation, $\mathrm{CO}_{2}$ from biomass incineration and $\mathrm{CH}_{4}$ from manure [17, 18]. The application of synthetic $(\mathrm{N})$ fertilizer and incorporation of crop residues into soil results in nitrous oxide $\left(\mathrm{N}_{2} \mathrm{O}\right)$ emissions. Similarly, the application of urea and lime to the soil results in carbon dioxide $\left(\mathrm{CO}_{2}\right)$ emissions [19]. The European Union is committed to reducing their greenhouse gas emissions by $20 \%$ until 2020 or $40 \%$ until 2030 compared to 1990 levels of the Kyoto Protocol [20].

The transformation toward low-carbon economy is determined by the adoption of appropriate practical actions in all sectors and industries, including agriculture [21]. Low energy, low releasing, low polluting and high efficiency are characteristics of "low-carbon agriculture." Low-carbon agricultural combines cleaner production and utilization of waste, and the concept is similar to the concepts of sustainable agriculture, ecological agriculture, and circular agriculture [22-24]. Carbon efficiency is considered not only from a practical but also from a theoretical point of view. The evolution of agricultural activities toward carbon efficiency is an important condition for balancing economic, environmental and social goals. The main goal in this case is slowing down (limiting) climate change and promoting sustainable development. The bases of the low-carbon agriculture concept are created by different scientific fields and disciplines. Understanding the conditions of low-carbon economic development through the analyses of interdependences and relationships between phenomena, concepts and objects is the subject of study, inter alia, in agricultural, technical and economic sciences.

The main objective of this paper is to outline the problem of low-carbon agriculture in Poland, with particular emphasis on the emission of methane and nitrous oxide. The paper presents the main determinants and problems related to the development of low-carbon agriculture in Poland. The source of information for writing the paper was literature of the subject and statistical data of the Central Statistical Office.

\section{Agricultural Emissions of Major Greenhouse Gases in Poland as Well as the Technical and Organizational Possibilities for their Reduction}

The main greenhouse gases are carbon dioxide $\left(\mathrm{CO}_{2}\right)$, nitrogen dioxide $\left(\mathrm{NO}_{2}\right)$ and methane $\left(\mathrm{CH}_{4}\right)$. Agriculture has a significant share in the total emissions of nitrous oxide $\left(\mathrm{N}_{2} \mathrm{O}\right)$ and methane $\left(\mathrm{CH}_{4}\right)$. Due to the possibility of limiting carbon emissions from agriculture through its sequestration in soils, the share of agriculture in net $\mathrm{CO}_{2}$ emissions in Poland is relatively small. Agricultural emissions are linked to both plant and animal production. The significance of the main greenhouse gas emissions from agricultural sources, in relation to the total emissions in Poland in 2014, is presented in Table 1, which identifies the streams of greenhouse gas emissions from plant and animal production.

Fundamental emissions from the point of view of consideration include nitrogen oxide (I), commonly referred to as "nitrous oxide" $\left(\mathrm{N}_{2} \mathrm{O}\right)$, a greenhouse gas that is 300 times more efficient than $\mathrm{CO}_{2}$ in terms of heat absorption. Nitric oxide is poorly soluble in water, is not eluted with precipitation, and its duration in the air is estimated to be about 150 years (it cumulates in the atmosphere). Much of the $\mathrm{N}_{2} \mathrm{O}$ emissions associated with human activity are caused by undesirable decomposition of nitrogen fertilizers in the soil (natural and mineral fertilizers) [27]. $\mathrm{N}_{2} \mathrm{O}$ emissions are not only affected by nitrogen input in soils but also other factors: soil temperature, oxygenation, availability of hydrocarbons, $\mathrm{pH}$ and soil humidity [28]. Taking into account the microbiological processes, nitrous oxide emissions correspond to denitrification and, to a lesser extent, nitrification [29]. Emissions of the aforementioned

Table 1. Share of agriculture in major greenhouse gas emissions in Poland in 2014.

\begin{tabular}{|c|c|c|c|c|c|c|}
\hline \multirow{2}{*}{ Specification } & \multicolumn{2}{|c|}{$\mathrm{CO}_{2}$} & \multicolumn{2}{c|}{$\mathrm{NO}_{2}$} & \multicolumn{3}{c|}{$\mathrm{CH}_{4}$} \\
\cline { 2 - 7 } & [thous. tonnes] & {$[\%]$} & [thous. tonnes] & {$[\%]$} & [thous. tonnes] & {$[\%]$} \\
\hline Total* & 277703.8 & 100 & 1654.62 & 100 & 66.48 & 100 \\
\hline Agriculture & 905.41 & 0.33 & 557.1 & 33.67 & 52.27 & 78.63 \\
\hline Intestinal fermentation & - & - & 491.78 & 29.72 & - & - \\
\hline Excrement management & - & - & 64.26 & 3.88 & 7.06 & 10.62 \\
\hline Agricultural soils & - & - & - & - & 45.17 & 67.95 \\
\hline Burning of plant residues & - & - & 1.06 & 0.06 & 0.04 & 0.06 \\
\hline Liming & 467.55 & 0.17 & - & - & - & - \\
\hline Use of urea & 437.86 & 0.16 & - & - & - & - \\
\hline
\end{tabular}

* Net emissions, ie taking into account emissions and removals from the sector "Land use, land use changes and forestry".

Source: $[25,26]$ 


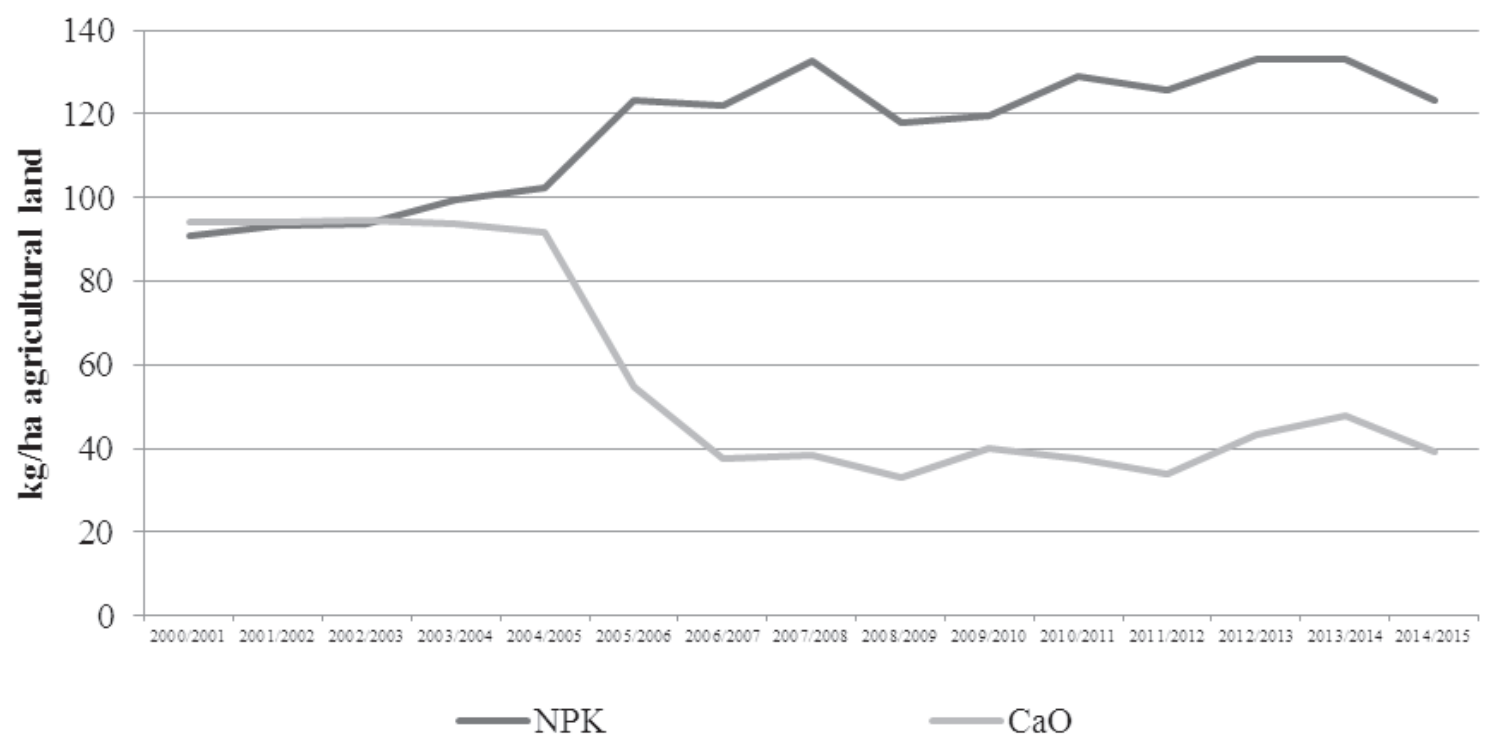

Fig. 1. Consumption of mineral (NPK) and calcium (CaO) fertilizers in Poland in 2000-2015. Source: [33]

compounds contribute to adverse changes in agricultural soil (acidification) and to the eutrophication of natural ecosystems. In addition, nitrous oxide contributes to the intensification of the greenhouse effect and contributes to the disappearance of the ozone zone [30].

According to data presented in Table 1, the main source of $\mathrm{N}_{2} \mathrm{O}$ emissions in Poland is agricultural soil. It should be emphasized that $\mathrm{N}_{2} \mathrm{O}$ emission from agricultural soils occurs directly and indirectly. $\mathrm{N}_{2} \mathrm{O}$ direct emissions are mainly due to the use of nitrogen fertilizers and the emission of $\mathrm{N}_{2} \mathrm{O}$ from organic nitrogen in animal faeces, while the indirect ones are related to ammonia $\left(\mathrm{NH}_{3}\right)$ emissions and nitrogen leaching [31,32]. An important source of $\mathrm{N}_{2} \mathrm{O}$ formation in Poland is the intensive supply of soil with nitrogen fertilizers. In 2014-2015 the level of mineral fertilizer consumption in Poland amounted to $123.2 \mathrm{~kg}$ NPK/ha agricultural land, including $69 \mathrm{~kg}$ of nitrogen. Essential in the researched subject are the levels of mineral and calcium fertilizer consumption (Fig. 1).

Between 2000 and 2004 Poland maintained relatively balanced consumption of mineral and calcium fertilizers. Between 2005 and 2015 very low levels of calcium fertilization were reported in Poland. It is worth stressing here that liming is counteracting denitrification processes that lead to nitrogen losses. The necessity of soil liming in Poland results from the very high proportion of acid soils in the structure of agricultural land (Table 2).

The above statement confirms the thesis that "actions aimed at increasing liming of soils" [35] should be intensified in Poland. The needs of soil liming in Poland, estimated on the basis of the National Agricultural Chemistry Station data, are presented in Table 3.

The problem of Polish agriculture in the context of a low-emission economy is also the emission of nitrogen oxides $\left(\mathrm{NO}_{\mathrm{x}}\right)$. However, as Marcinkowski [36] notes, no specific actions are currently planned to be taken to limit their emission from agricultural sources. On the other hand, the potential for reducing nitrous oxide emissions is seen in the increase in fertilizer use efficiency. Changes in agricultural practices related to agrotechnical aspects are necessary in this respect. There are also potential sources of $\mathrm{N}_{2} \mathrm{O}$ emissions in animal production: animal emissions, emissions from enclosed animal waste, and excreta emissions from the soil during grazing.

Agriculture also accounted for $33.67 \%$ of methane emissions in Poland in 2014. The largest share of methane emissions in Polish agriculture is intestinal

Table 2. Structure of soil reaction in Poland in 2012-2015*.

\begin{tabular}{|c|c|c|c|c|c|c|}
\hline \multirow{2}{*}{$\begin{array}{l}\text { Number } \\
\text { of samples }\end{array}$} & \multirow{2}{*}{$\begin{array}{c}\text { Area } \\
\text { examined }\end{array}$} & \multicolumn{5}{|c|}{ Soil reaction } \\
\hline & & $\begin{array}{c}\text { Very acid } \\
\mathrm{pH} \leq 4.5\end{array}$ & $\begin{array}{c}\text { Acid } \\
\mathrm{pH} 4.6-5.5\end{array}$ & $\begin{array}{l}\text { Slightly acid } \\
\text { pH 5.6-6.5 }\end{array}$ & $\begin{array}{c}\text { Neutral } \\
\mathrm{pH} \text { 6.6-7.2 }\end{array}$ & $\begin{array}{l}\text { Alkaine } \\
\mathrm{pH}>7.2\end{array}$ \\
\hline [pcs.] & [thous. ha] & \multicolumn{5}{|c|}{$[\%]$} \\
\hline 1565893 & 3861.9 & 13 & 26 & 34 & 18 & 9 \\
\hline
\end{tabular}

*data of the National Chemistry-Agriculture Station.

Source: [34] 
Table 3. Soil liming needs in Poland in 2012-2015*.

\begin{tabular}{|c|c|c|c|c|c|c|}
\hline \multirow{2}{*}{$\begin{array}{l}\text { Number } \\
\text { of samples }\end{array}$} & \multirow{2}{*}{$\begin{array}{c}\text { Area } \\
\text { examined }\end{array}$} & \multicolumn{5}{|c|}{ Liming needs } \\
\hline & & Required & Needed & Recommended & Local & Needless \\
\hline [pcs.] & [thous. ha] & \multicolumn{5}{|c|}{$[\%]$} \\
\hline 1565893 & 3861.9 & 19 & 15 & 17 & 17 & 32 \\
\hline
\end{tabular}

* data of the National Chemistry-Agriculture Station.

Source: [34]

Table 4. Standard methane emissions coefficients from intestinal fermentation and animal manure.

\begin{tabular}{|c|c|c|}
\hline \multirow{2}{*}{$\begin{array}{c}\text { Group } \\
\text { of animals }\end{array}$} & \multicolumn{2}{|c|}{$\mathrm{CH}_{4}$ emission coefficient } \\
\cline { 2 - 3 } & \multicolumn{2}{|c|}{$\left[\mathrm{kg} \cdot \mathrm{pc}^{-1} \cdot \mathrm{year}^{-1}\right]$} \\
\hline Dairy cows & 99 & 15 \\
\hline Othestinal fermentation & Animal excreta \\
\hline Sheep & 58 & 8 \\
\hline Goats & 8 & 0.19 \\
\hline Horses & 5 & 0.13 \\
\hline Pigs & 18 & 1.56 \\
\hline Poultry & 1.5 & 4 \\
\hline
\end{tabular}

Source: [37]

fermentation, which largely depends on the number of ruminant animals, and the type and weight of feed used. Regarding agricultural sources, methane is also emitted from livestock manure, and the impact on the volume of emissions is mainly influenced by the way it is stored (temperature conditions and oxygen availability). Standard methane emission coefficients from intestinal fermentation and animal excreta are presented in Table 4.

As evidenced by the above statement, the $\mathrm{CH}_{4}$ emission coefficient is the highest in the dairy cow category, which results from the process of food digestion. Monogastric animals, including poultry, emit less greenhouse gas than ruminants. Due to the animal population in Poland (Table 5) and the methane emissions coefficients from intestinal fermentation and animal excreta presented earlier, the issue of intestinal fermentation in livestock production concerns mainly cattle. In turn, the main source of emissions in the case of monogastric animals is animal excreta.

The literature on the subject includes lots of information on determining the emission coefficients of harmful gases from animal production that take into account important parameters, e.g., the milk yield of cows (Table 6).

Limiting methane emissions can be achieved through the use of feed additives for ruminants. It is important to adjust food doses (nutrients and nutrient

Table 5. Livestock population in Poland (December 2015).

\begin{tabular}{|c|c|c|c|c|}
\hline \multirow{3}{*}{ Specification } & \multirow{2}{*}{ Total } & \multicolumn{2}{|c|}{ Sector } & \multirow{3}{*}{$\begin{array}{c}\text { Structure of livestock in total } \\
{[\%]}\end{array}$} \\
\hline & & Private & Public & \\
\hline & \multicolumn{3}{|c|}{ [thous. pcs.] } & \\
\hline Cattle in total & 5762.5 & 5681.7 & 80.9 & 100 \\
\hline Cows & 2302.8 & 2269 & 33.8 & 40 \\
\hline Other cattle & 3459.7 & 3412.7 & 47.1 & 60 \\
\hline Sheep in total & 221.2 & 212.2 & 9 & 100 \\
\hline Ewes & 140 & 133.8 & 6.2 & 63.3 \\
\hline Poultry in total ${ }^{\mathrm{a}}$ & 153209.5 & 153177.4 & 32.1 & $\mathrm{X}$ \\
\hline Chicken poultry & 139588 & 139577.2 & 10.9 & $\mathrm{X}$ \\
\hline Pigs in total ${ }^{\mathrm{b}}$ & 10590.2 & 10533.7 & 56.5 & 100 \\
\hline Sows & 814.4 & 809.1 & 5.3 & 7.7 \\
\hline Other pigs & 9775.8 & 9724.6 & 51.2 & 92.3 \\
\hline
\end{tabular}

\footnotetext{
${ }^{\text {a }}$ Together - chicken poultry, geese, ducks, turkeys and other poultry

${ }^{\mathrm{b}}$ Until June 2014

Source: [38]
} 
Table 6. Methane emissions by cows depending on yield.

\begin{tabular}{|c|c|c|}
\hline Annual milk yield & Emission* $\mathrm{CH}_{4}$ & Emission* $\mathrm{CH}_{4}$ \\
\hline$[\mathrm{kg}]$ & {$[\mathrm{kg} / \mathrm{year} / \mathrm{cow}]$} & {$[\mathrm{g} / \mathrm{kg}$ of milk $]$} \\
\hline 4000 & 93.84 & 23.46 \\
\hline 5000 & 101.20 & 22.10 \\
\hline 6000 & 108.12 & 18.02 \\
\hline 7000 & 116.20 & 16.10 \\
\hline 8000 & 122.40 & 15.30 \\
\hline 9000 & 131.60 & 14.10 \\
\hline 10000 & 136.00 & 13.60 \\
\hline 11000 & 140.06 & 12.80 \\
\hline 12000 & 146.88 & 12.24 \\
\hline
\end{tabular}

* Methane emitted only from the digestive tract

Source: [39]

value) to the requirements of the animals, taking into account their different phases of reproductive cycle. The feeding way of reducing gas emissions in livestock farming is not the only method used. The literature highlights many technologies and techniques that reduce emissions of burdensome gases arising from livestock farming. This is especially important for industrial farms where huge quantities of animal excreta are produced (sources of not only odorous but also greenhouse gases) [40]. Emissions of odour and greenhouse gases also occur in livestock buildings, and reductions in this regard can be achieved, among others, through a suitable animal maintenance system and the use of additives to litter and droppings. From the environmental point of view it is also necessary to neutralize the gases generated during slurry storage. Reduction of methane emissions can be achieved by appropriate selection of cattle breeds. According to Podkówka [39], highyielding cows, producing $8-10,000 \mathrm{~kg}$ of high-protein milk, less heavily pollute the environment with methane. For example, Holstein-Friesian cows producing lowfat milk are more environmentally friendly than other breeds producing high-fat milk.

Greenhouse gas emissions from agricultural production are also affected by the mechanization of agriculture. Regarding the scope of considerations in this paper, it is important to consider the emissions of air pollutants as a result of the use of agricultural tractors (Table 7).

Farm tractors, as well as other diesel-powered vehicles, produce gases containing carbon monoxide (CO), hydrocarbons (HC), particulate matter (PM) and nitrogen oxides $\left(\mathrm{NO}_{\mathrm{x}}\right)$. As the data in Table 7 show, agricultural tractors account for more than $6 \%$ of nitrogen oxide emissions from the total means of transport in Poland. Other emissions (e.g., $\mathrm{N}_{2} \mathrm{O}$, $\mathrm{PM}, \mathrm{SO}_{2}$ and $\mathrm{Pb}$ ) account for about $2 \%$ of the total emissions of means of transport. From the point of view of emission reductions, the emission limit values for four harmful substances, such as $\mathrm{CO}, \mathrm{HC}, \mathrm{NO}_{\mathrm{x}}$ and $\mathrm{PM}$, are relevant for the use of farm tractors in light of applicable emission standards. The first emission standards for diesel engines above $37 \mathrm{~kW}$ (50KM) for non-road vehicles (including agricultural machines) were introduced in 2001 (Stage 1). Subsequently, more stringent emission standards (Stage II and current Stage IIIA) were introduced in 2002-2008. Since January 2011, Stage III B (known in the U.S. as Tier 4 Interim) has been in place [41]. In 2014, the Stage IV (Tier 4 final) emission standard entered into force. These are very important issues in terms of emissions and evolution toward a low-carbon economy.

As Pawlak [42] notes, the advanced age of most agricultural mechanization measures held by farmers in Poland is reflected in the technical conditions of these measures. It affects the level of fuel per unit consumption. It should be emphasized, however, that in Polish agriculture there has been improvement in the standard of technical equipment (especially regarding

Table 7. The importance of agricultural tractors in the emission of air pollutants in the group of means of transport.

\begin{tabular}{|c|c|c|c|c|c|c|c|c|c|}
\hline \multirow{4}{*}{ Specification } & \multicolumn{9}{|c|}{ Emission } \\
\hline & \multirow{2}{*}{$\mathrm{CO}_{2}$} & \multirow{2}{*}{$\mathrm{CH}_{4}$} & \multirow{2}{*}{$\mathrm{N}_{2} \mathrm{O}$} & \multirow{2}{*}{$\mathrm{CO}$} & NMLZO & \multirow{2}{*}{$\mathrm{NO}_{\mathrm{x}}$} & \multirow{2}{*}{ PM } & \multirow{2}{*}{$\mathrm{SO}_{2}$} & \multirow{2}{*}{$\mathrm{Pb}$} \\
\hline & & & & & NMVOC & & & & \\
\hline & \multicolumn{9}{|c|}{ [thous. tonnes] } \\
\hline Total $^{\mathrm{a}}$ & 42332.6 & 3.77 & 1.82 & 563.12 & $117.21^{b}$ & 220.6 & $74.70^{c}$ & 1.21 & 0.014 \\
\hline \multirow[t]{2}{*}{ Agricultural tractors } & 845.4 & 0.05 & 0.04 & 12.32 & 2.13 & 13.84 & 1.38 & 0.03 & - \\
\hline & \multicolumn{9}{|c|}{$[\%]$} \\
\hline Total $^{\mathrm{a}}$ & 100 & 100 & 100 & 100 & 100 & 100 & 100 & 100 & 100 \\
\hline Agricultural tractors & 2.00 & 1.33 & 2.20 & 2.19 & 1.82 & 6.27 & 1.85 & 2.48 & 2.00 \\
\hline
\end{tabular}

a Excluding emissions from biofuels

${ }^{\mathrm{b}}$ Including evaporative emissions (50.8 thous. tonnes)

${ }^{\mathrm{c}}$ Including the emissions from the wear of tires, brakes and road pavements (58.1 thous. tonnes)

Source: $[25,26]$ 
higher-powered tractors) of family farms, which has resulted from the possibility of obtaining EU subsidies. Undoubtedly, farm machinery in Poland requires further modernization and adaptation to environmentally friendly technologies [43].

\section{Institutional Support for the Development of Low-Carbon Agriculture in Poland}

Limiting the emissivity of agriculture in Poland is one of the main objectives of the agricultural policy being implemented. The actions aimed at environmental protection in rural areas in Poland intensified after the accession of Poland to the EU, particularly along with the implementation of the provisions of the Directive of the European Parliament and of the Council 2009/29/EC ${ }^{1}$. The Rural Development Programme (RDP), which had been implemented in Poland in 2007-2013, enabled modernization of agricultural holdings towards reduction of emissions, which included the purchase of solar collectors and construction of biogas plants. Despite this fact, there is still a large untapped potential in this respect in Poland [44]. In the new financial perspective (2014-2020), there are even more options available in this scope. Under the currently implemented RDP in agri-environmentclimate measures, there was distinguished Package 1 - Sustainable Agriculture. The purpose of this package is, among other things, to prevent the loss of organic matter in soil and the rational use of fertilizers. The beneficiary implementing this package is obliged, inter alia, to carry out soil analysis twice and to execute the fertilization plan every year. The elements associated with the rational management of agrochemicals are also present in other packages. For example Package 2 - Soil and Water Protection consists in the promotion of agricultural practices aimed at counteracting the water erosion of soil, loss of organic matter and water pollution with components washed out from soils. However, it is necessary to perform further work on economic instruments aimed at encouraging the farmers to make changes in their production systems as well as on an adequate manner of promoting pro-ecological behaviours among farmers and other rural residents.

The cooperation between scientific centres and business is extremely important for the problems examined here. One of interesting programmes in this scope in Poland is the project entitled "Support for lowcarbon agriculture able to adapt to observed climate change in the perspective of 2030 and 2050" (acronym: LCAgri), funded from the "Biostrateg" program of the National Research and Development Centre. The aim of the project is to improve the efficiency of utilizing

EU countries have committed themselves to reduce the emissions of greenhouse gases (GHG) before 2020 by at least $20 \%$ in relation to base year $(1990)$. the resources by implementing innovative low-carbon agricultural practices and promoting the sustainable use of mineral fertilizers by agricultural holdings in Poland. The project focuses on the possibilities of implementing the methods for sustainable use of mineral fertilizers in combination with modifications of other elements of the production technology. An evaluation conducted properly under the project will provide a basic tool for identifying the main sources of greenhouse gas emissions and the priority areas in which low-carbon measures should be taken.

Agricultural advisory services can also play a huge role in supporting the development of lowcarbon agriculture in Poland. At the same time, agricultural advisory services face new challenges in this scope - both in terms of the content and the form of communication. The institutional support from the agricultural advisory agencies must perform advisory, educational and informative functions, as well as the function of dissemination in an appropriate form. A well-organized and effective agricultural advisory system in the scope of low-carbon practices requires not only training on the modernization of production processes and the distribution and use of energy, but also flexibility and the ability to adapt to climate change and to prevent and manage the risk. A reduction of the emissivity in agriculture is possible by means of a gradual change in the behaviours of business units in agriculture aimed at improving energy efficiency by modernizing the processes of energy production and use. It is very difficult to implement such changes, because farmers often say that the restrictions in this scope would limit their competitiveness and in consequence could result in their lower incomes. Economic factors shaping the conditions of agricultural production force its intensification and thus limit the possibility of using mitigation practices without incurring additional costs of their implementation. As mentioned earlier, a rational fertilization management is an important element of low-carbon agriculture in Poland. The improvement in this scope can be achieved by: reduction of doses of nitrogen fertilization; an appropriate selection of the form of nitrogen in fertilizers and the use of inhibitors of nitrification and urease; and regulation of soil $\mathrm{pH}$. According to the studies conducted by Sosulski et al. [45], the use of nitrification inhibitors or urease and the afforestation of the poorest arable lands (valuation class VI) may be an effective practice that would allow for reducing the emissions of $\mathrm{N}_{2} \mathrm{O}$. Agricultural advisory agencies in Poland should pay more attention to these issues - both in terms of microeconomic benefits (economic rationality) and benefits for the entire society.

\section{Summary}

On the one hand, the low-carbon economy is a response to the challenges associated with climate change and the needs to counteract disturbances in 
ecosystems, and on the other hand it is a conscious creation of agribusiness development in a more sustainable way. Transformation of the agriculture towards low-carbon practices is associated with the transformation of production and consumption processes along with simultaneous reduction in emissions of pollutants and greenhouse gases, minimization of waste and ineffective use of natural resources, preservation of biological diversity, and improving energy security. The necessity for a low-carbon transformation in Polish agriculture results from the internal efforts of the state and society aimed at reducing greenhouse gas emissions, but first of all from the efforts made by the government to adapt the national regulations to the recommendations and regulations of the EU's climate policy and other international obligations of Poland.

Agricultural activities in Poland play an important role in the economy, but also generate significant GHG emissions to the atmosphere. Polish agriculture faces many difficult challenges in the transition toward a low-carbon economy. It is connected with limiting the emission of ammonia and greenhouse gases from animal production and emissions of nitrogen oxides, including nitrous oxide, from natural and mineral fertilizers. Reducing emissions, among others, of greenhouse gases from agriculture requires the introduction of innovative techniques and tools that increase the efficiency of the use of agricultural inputs, animal waste, and crop residues. The results presented in this study are limited and do not cover the whole range of factors affecting agricultural pollution in Poland. The condition of a low-carbon economy development in agriculture is smart growth based on knowledge and innovation. It is necessary, inter alia, to use innovative means of agricultural production with relatively low environmental pressure (e.g., biofertilizers and biopesticides), implementing precision agriculture (using GPS), developing low emission energy sources on farms (e.g., agricultural biogas energy plants), using crop rotation plants with a positive index of reproduction of soil organic matter and adding nitrogen compounds to feed. The problems of rational management of the environment in the context of a low-carbon economy are also related to the technical equipment used.

\section{Acknowledgements}

This study was conducted and financed within the framework of the research project "The state and prospects of the development of low-carbon agriculture in Poland and the behaviour of agricultural producers," granted by the National Science Centre in Poland, program SONATA, grant No. 2016/21/D/HS4/00087.

\section{Conflict of Interest}

The author declares no conflict of interest.

\section{References}

1. FOXON T.J. A coevolutionary framework for analysing a transition to a sustainable low carbon economy. Ecological Economics, 70 (12), 2258, 2011.

2. HOU J., ZHANG P., TIAN Y., YUAN X., YANG Y. Developing low-carbon economy: Actions, challenges and solutions for energy savings in China. Renewable Energy, 36 (11), 3037, 2011.

3. TAVONI M., DE CIAN E., LUDERER G., STECKEL J. C., WAISMAN H. The value of technology and of its evolution towards a low carbon economy. Climatic Change, 114 (1), 39, 2012.

4. GRADZIUK P., GRADZIUK B. Gospodarka niskoemisyjna - nowe wyzwanie dla gmin wiejskich. Wieś i Rolnictwo, 1, 105, 2016 [In Polish].

5. BEBBINGTON J. Carbon trading: accounting and reporting issues. European Accounting Review, 17 (4), 697, 2008.

6. BRYNGELSSON D., WIRSENIUS S., HEDENUS F., SONESSON U. How can the EU climate targets be met? A combined analysis of technological and demand-side changes in food and agriculture. Food Policy, 59, 152, 2016.

7. DZIKUĆ M. Problems associated with the low emission limitation in Zielona Góra (Poland): Prospects and challenges. Journal of Cleaner Production, 166, 81, 2017.

8. NORSE D. Low carbon agriculture: Objectives and policy pathways. Environmental Development, 1, 25, 2012.

9. DZIKUĆ M., ADAMCZYK J., PIWOWAR A. Problems associated with the emissions limitations from road transport in the Lubuskie Province (Poland). Atmospheric Environment, 160, 1, 2017.

10. XIN X., YUDING W., JIANZHONG W. The Problems and Strategies of the Low Carbon Economy Development. Energy Procedia, 5, 1831, 2011.

11. HUISINGH D., ZHANG Z., MOORE J. C., QIAO Q., LI Q. Recent advances in carbon emissions reduction: policies, technologies, monitoring, assessment and modeling. Journal of Cleaner Production, 103, 1, 2015.

12. PAOLOTTI L., BOGGIA A., CASTELLINI C., ROCCHI L., ROSATI A. Combining livestock and tree crops to improve sustainability in agriculture: a case study using the Life Cycle Assessment (LCA) approach. Journal of Cleaner Production, 131, 351, 2016.

13. VETTER S.H., SAPKOTA T.B., HILLIER J., STIRLING C.M., MACDIARMID J.I., ALEKSANDROWICZ L., GREEN R., JOY E., DANGOUR A., SMITH P. Greenhouse gas emissions from agricultural food production to supply Indian diets: Implications for climate change mitigation. Agriculture, Ecosystems \& Environment, 237, 234, 2017.

14. MCGINN S.M. Measuring greenhouse gas emissions from point sources in agriculture. Canadian Journal of Soil Science, 86 (3), 355, 2006.

15. FLESSA H., RUSER R., DÖRSCH P., KAMP T., JIMENEZ M.A., MUNCH J.C., BEESE F. Integrated evaluation of greenhouse gas emissions $\left(\mathrm{CO}_{2}, \mathrm{CH}_{4}\right.$, $\mathrm{N}_{2} \mathrm{O}$ ) from two farming systems in southern Germany. Agriculture, Ecosystems and Environment, 91 (1-3), 175, 2002.

16. YAN M., CHENG K., LUO T., YAN Y., PAN G., REES,R. M. Carbon footprint of grain crop production in China - based on farm survey data. Journal of Cleaner Production, 104, 130, 2015. 
17. REAY D.S., DAVIDSON E.A., SMITH K.A., SMITH P., MELILLO J.M., DENTENER F., CRUTZEN P.J. Global agriculture and nitrous oxide emissions. Nature Climate Change, 2, 410, 2012.

18. HAVLÍK P., VALIN H., MOSNIER A., OBERSTEINER M., BAKER J.S., HERRERO M., RUFINO M.C., SCHMID E. Crop productivity and the global livestock sector: Implications for land use change and greenhouse gas emissions. Am. J. Agric. Econ., 95 (2), 442, 2013.

19. TONGWANE M., PIKETH S., STEVENS L., RAMOTUBEI T. Greenhouse gas emissions from road transport in South Africa and Lesotho between 2000 and 2009. Transportation Research Part D: Transport and Environment, 37, 1, 2015.

20. SOLILOVÁ V., NERUDOVÁ D. Evaluation of greenhouse gas emissions and related aspects: case of the Czech Republic. Acta Universitatis Agriculturae et Silviculturae Mendelianae Brunensis, 63, 281, 2015.

21. REISINGER A., HAVLIK P., RIAHI K., VAN VLIET O., OBERSTEINER M., HERRERO M. Implications of alternative metrics for global mitigation costs and greenhouse gas emissions from agriculture. Clim. Chang., 117, 677, 2013.

22. KANG M. A Brief Analysis of Low-Carbon Agriculture Development Pattern. Business and Management Research, 2 (2), 96, 2013.

23. XIONG C., YANG D., HUO J., ZHAO Y. The relationship between agricultural carbon emissions and agricultural economic growth and policy recommendations of a lowcarbon agriculture economy. Pol. J. Environ. Stud., 25 (5), 2187, 2016.

24. PIWOWAR A. Realizacja koncepcji zrównoważonego rozwoju w produkcji agrochemikaliów. Metody, narzędzia i techniki zarządzania. Przemysł Chemiczny, 95, 700, 2016 [In Polish].

25. Ochrona Środowiska 2016. GUS, Warszawa 2016 [In Polish].

26. Ochrona Środowiska 2017. GUS, Warszawa 2017 [In Polish].

27. KRUK J., WILK M. Neutralizacja podtlenku azotu procesy i katalizatory. In Ryczkowski J (ed.) Absorbenty i katalizatory. Wyd. Uniwersytetu Rzeszowskiego, Rzeszów, 23, 2012 [In Polish].

28. SHEPHERD M.F., BARZETTI S., HASTIE D.R. The production of atmospheric NOx and N20 from a fertilized agricultural soil. Atmos. Environ., 25A, 1961, 1991.

29. JAROSZ Z., FABER A. Możliwości ograniczenia emisji rolniczych $\mathrm{z}$ uprawy kukurydzy przeznaczonej do produkcji bioetanolu. Roczniki Naukowe SERiA, XVIII, 120, 2016 [In Polish].

30. SAPEK A. Emisja tlenków azotu (NOx) z gleb uprawnych i ekosystemów naturalnych do atmosfery. WodaŚrodowisko-Obszary Wiejskie, 8, 283, 2008 [In Polish].
31. JAROSZ Z., FABER A. Możliwości ograniczenia emisji rolniczych z uprawy pszenicy przeznaczonej na cele paliwowe. Problemy Inżynierii Rolniczej, 2 (88), 75, 2015 [In Polish].

32. KOLASA-WIĘCEK A. Modelowanie emisji podtlenku azotu ze źródeł rolniczych z wykorzystaniem regresji liniowej. Journal of Research and Applications in Agricultural Engineering, 58 (1), 86, 2013 [In Polish].

33. Rynek środków produkcji dla rolnictwa. Analizy Rynkowe, 43, 10, 2016 [In Polish].

34. Środki produkcji w rolnictwie w roku gospodarczym 2015/2016. GUS, Warszawa 2017 (available on-line at http://stat.gov.pl/obszary tematyczne/rolnictwo/lesnictwo/ rolnictwo/srodki-produkcji-w-rolnictwie-w-rokugospodarczym-20152016.6.13.html., accessed 10.03.2018).

35. PIWOWAR A. Zużycie nawozów wapniowych w Polsce a potrzeby wapnowania gleb. Technika Rolnicza. Ogrodnicza. Leśna, 1, 24, 2015 [In Polish].

36. MARCINKOWSKI T. Emisja gazowych związków azotu z rolnictwa. Woda-Środowisko-Obszary Wiejskie, 10, 175, 2010 [In Polish].

37. MIELCAREK P. Weryfikacja wartości współczynników emisji amoniaku i gazów cieplarnianych z produkcji zwierzęcej. Inżynieria Rolnicza, 4 (139), 267, 2012 [In Polish].

38. Zwierzęta gospodarskie w 2015 r. GUS, Warszawa, 48, 2016 [In Polish].

39. PODKÓWKA Z., PODKÓWKA W. Emisja gazów cieplarnianych przez krowy. Przegląd Hodowlany, 3, 1, 2011 [In Polish].

40. SMURZYŃSKA A., DACH J., CZEKAŁA W. Technologie redukujące emisje uciążliwych gazów powstających podczas chowu zwierząt gospodarskich. Inżynieria Ekologiczna, 47, 189, 2016 [In Polish].

41. KRUCZYŃSKI S. W., CHRUPEK B., WOJS M. Metody ograniczania poziomu emisji stosowane w silnikach maszynach budowlanych w świetle wymagań norm emisji spalin: STAGE III B/ STAGE IV. Zeszyty Naukowe Instytutu Pojazdów, 1, 109, 2014 [In Polish].

42. PAWLAK J. Rolnictwo a środowisko naturalne. Problemy Inżynierii Rolniczej, 1, 17, 2015 [In Polish].

43. MARCZUK T. Struktura wyposażenia gospodarstw rolnych w ciągniki i maszyny do uprawy zbóż na terenie województwa podlaskiego. Problemy Inżynierii Rolniczej, 3 (81), 39, 2013 [In Polish].

44. PIWOWAR A., DZIKUĆ M., ADAMCZYK J. Agricultural biogas plants in Poland - selected technological, market and environmental aspects. Renewable \& Sustainable Energy Reviews, 58, 69, 2016.

45. SOSULSKI T., SZYMAŃSKA M., SZARA E. Ocena możliwości redukcji emisji $\mathrm{N}_{2} \mathrm{O}$ z gleb uprawnych Polski. Soil Science Annual, 68 (1), 55, 2017 [In Polish]. 